\title{
(AB)USE OF GOLDEN PARACHUTES IN STATE-OWNED COMPANIES IN THE FORMER YUGOSLAVIA
}

\author{
Nebojša R. Mitić ${ }^{1}$ \\ Slaviša M. Đorđević ${ }^{2}$
}

DOI: https://doi.org/10.31410/LIMEN.2020.271

\begin{abstract}
Golden parachutes represent one of the preventive defence antitakeover measures based on which contracts are concluded with the engagement of team of managers of the target company, promising them the payment of profitable compensation in case of occurrence of transactions related to takeover of control (purchase of a certain percentage of shares or direct offer to shareholders for a certain percentage of company shares). Contract rights called the golden parachutes are activated by the creation of one or more alternative events, or "triggers."

(Un)intentional incorrect application of the golden parachutes may have not only significant negative consequences on the future performance of companies, but it can also deter potential investors from the decision to invest their capital in companies that have entered into such agreements with the engaged team of managers. Numerous cases of incorrect application of the golden parachutes can be found in the former socialist countries, as well as in the countries that emerged from the dissolution of Yugoslavia.
\end{abstract}

Keywords: Antitakeover defences, Preventive measures, Golden parachutes, (Ab)use.

\section{INTRODUCTION}

7 he 'hostile takeovers' term was introduced during the 1980s, to explain the merger and acquisition processes in which there is no consent of the shareholders and/or the management of the prospective target corporations with the transaction proposed by the acquirer. On one hand, such situations forced the acquirers to develop certain takeover tactics, whereas, on the other hand, the target corporations were forced to develop measures to help them maintain their independence. The golden parachute represents one of the relatively broadly implemented measures, both in corporations in the countries with the developed market economy, and in corporations in the countries formed after the dissolution of the socalled Socialist Bloc and/or countries formed after the dissolution of the former SFRY. The essence and characteristics of this antitakeover defence, and some of its (ab)uses typical for our region will be further discussed in this paper.

\section{ANTITAKEOVER DEFENCES}

Many antitakeover defences were developed by the US investment banks in the 1970s and 1980s. The defences were used even by the companies in Germany and France that are wary of belligerent corporations. For example, together with J. P. Morgan, Deutsche Bank, the Daimler-Chrysler investment bank, took part in the development of the defence strategy of the aforementioned company at the beginning of 2001 (Sudarsanam, 2003, p. 466).

Academy of Vocational Studies of Southern Serbia, Blace Department

Faculty of Economy Priština-Kosovska Mitrovica 
The dilemma whether the corporation managers actually act as true agents of the owner, trying to generate satisfactory revenue for the shareholders, or they manage the corporation in order to realize their own interests (target function) is fully expressed when it comes to the adoption and implementation of antitakeover defence measures. ${ }^{3}$ On one hand, supporters of implementation of antitakeover defence measures by the target corporation management point out that the resistance to takeover will increase the amounts of compensation the acquirer offers to the target corporation shareholders, which de facto is in the interest of the (co)owners (hypothesis on protecting the interest of shareholders). ${ }^{4}$ On the other hand, the opponents of adoption and implementation of antitakeover defence measures emphasize the protection of interests of target corporation management and their status, position and privileges they have (hypothesis on preservation of managerial chairs) (Bragg, 2014, p. 122). ${ }^{5}$

The fact that the managers not only manage, but frequently (co)own the companies they are tasked with managing impacts their conduct with hostile offers, as the intensity of their resistance to takeover is significantly lower in the situations when their share in the target corporation capital is significant. This happens because the managers expect that they will be able to cover the negative consequences occurring after takeover of the company they manage (loss of job and/or loss of status and privileges) with the premium paid by the acquirer above the prevailing market price of the target company shares. Contrary to that, the intensity of the resistance will be higher in the situations of a lower ownership share of the existing target corporation management, so the loss caused by the loss of job and status cannot be completely covered by the premiums obtained in case of a takeover (Ruback, 1988, p. 53).

From the point of view of the shareholders of both companies engaged in a transaction, particularly the target corporation shareholders, the managers need to try "to resists the offer to the point where the premium will be increased to the maximum, without endangering the chance to realize a successful transaction." (Sudarsanam, 200, p. 507)

There are numerous antitakeover defence measures, and different authors classify them in different ways. ${ }^{6}$ For example, the most frequently used one is the division of all measures depending on whether they have been adopted in order to defend the target company from a

3 For more details on agency issues, see: Predić, B., Ivanović-Đukić, M., "Metod za rešavanje agencijskog problema," Ekonomske teme, 1/10, Ekonomski fakultet, Niš, str. 1-12, Radović, V., "Uticaj agencijskih problema na pravo akcionarskih društava i korporativno upravljanje,“ u: Vasiljević, M., Radović, V., (urednici), Korporativno upravljanje, Zbornik radova, Pravni fakultet, Beograd, 2008., str. 235-65.

Apart from the assumption that the resistance to takeover will increase the price the prospective acquirer offers to the target corporation shareholders for their ownership shares, the frequent argument for the implementation of antitakeover measures is the existence of the hidden values that the target corporation owns, that are not available to the public (plans, strategies, ideas, patents, etc.), as well as the perception of managers that the company they manage is underestimated by the securities market. According to Ruback, R. S., "An Overview of Takeover Defenses," in Auerbach, A. J. (ed.), Mergers and Acquisitions, National Bureau of Economic Research, The University of Chicago Press, Ltd., London, 1988., p. 51.

5 The author emphasizes two basic reasons to oppose the takeover bids: valuation, or sale of target company shares at higher price, or generating higher revenues in future by implementing the strategy to be developed by the existing management; and the power, reflected in the desire to defend the position held by the existing management in the attacked target company.

$6 \quad$ For more details on antitakeover defence measures, see: Bragg, S. M., op. cit., p. 122-9; DePamphilis, D. M., Mergers, Acquisitions, and Other Restructuring Activities, Eighth edition, Academic Press, San Diego, 2015., p. 108-23; Đorđević, S. M., Poslovne kombinacije - Računovodstveni aspekt, monografija, Ekonomski fakultet Priština-Kosovska Mitrovica, 2007., str. 93-107; Gaughan, P. A., Mergers, Acquisitions, and Corporate Restructurings, Sixth edition, John Wiley \& Sons, Inc., New Jersey, 2015., p. 189-247; Ruback, R. S., op. cit. 53-65; Sudarsanam, S., op. cit., p. 507-23. 
takeover attempt, the target company has already been attacked, or it has already received a takeover offer, and it is forced to defend through the implementation of appropriate measures. In this regard, all the defence measures can be divided into:

- Preventive, preparatory, strategic, pre-bid or pre-offer defences - the essence of which is reflected in attempts to deter the prospective acquirers from attempting to attack the target corporation. The most frequently mentioned antitakeover defences are the following: corporate charter amendments, poison pill, golden parachutes, and many others, and

- Active, reactive, tactical, post-bid or post-offer defences - a reaction of target corporation management and shareholders to the already sent takeover bid. The most significant active measures are: greenmail or targeted share repurchase, white knight, capital structure changes, litigation, and counter-tender offer or Pac-Man defence.

We will try to explain the essence of the golden parachutes in more detail below, as we believe it is one of the most significant preventive measures of antitakeover defence. We will then present certain specificities of the (un)intentional abuse of the golden parachutes in the Republic of Serbia, and the neighbouring countries (the Republic of Croatia).

\section{PREVENTIVE ANTITAKEOVER DEFENCE MEASURES}

The prospective target corporation attempts to deter possible acquirers from a possible takeover in many ways. Different authors usually use the same names, although they classify them in different ways, but there are attempts to rename certain preventive defence measures. ${ }^{7}$ For example, Sudarsanam divides the preventive defence measures into internal and external (Sudarsanam, 2003, p. 507-8). Internal defence measures are the actions or decisions resulting in the change of internal structure or nature of business of the prospective target corporation. External defence measures are the actions aimed at impacting the perception of possible acquirers on the adopting company, as well as providing early warning signals on prospective acquirers. On the other hand, Bragg classifies all preparatory or preventive measures into four separate groups, depending on whether they impact certain integrative processes of the target corporations (preparatory defences - acquisitions), they are focused on installing or complying with certain legal regulations (preparatory defences - legal), they impact a significant change of the target corporation financial structure (preparatory defences - financial) or they are focused on changes in the production process (preparatory defences - operational) (Bragg, 2014, p. 123-6). Gaughan mentions an interesting observation, stating that the adoption and implementation of defences seems like "building the walls of a house, as higher and more resistant ramparts need to be built time after time, as the attackers (the acquirers - authors' note) ... dedicate a lot of time to overcoming these obstacles." (Gaughan, 2015, p. 189-247) Without trying to accept any of the aforementioned divisions of antitakeover preventive or preparatory measures, we will further elaborate only on the golden parachutes, noting that the companies simultaneously use several measures to make their attempts of defence as successful as possible (Brealey, Myers, \& Marcus, 2007, p. 586-8). ${ }^{8}$

$7 \quad$ For example, some authors consider all preventive antitakeover defences aimed at making the target company shark repellent, whereas others believe that the adoption of the amendments to the corporate articles of association actually represents the defence measure to make the company shark repellent and help deter the sharks from attempting to attack attempts.

$8 \quad$ There are numerous examples to support the aforementioned statement on the implementation of several defence measures that would lead to withdrawal of bidder, or sending an offer to target corporation shareholders and management to meet their interests. One of them is the example of Oracle that managed to gain control over PeopleSoft only after struggling for 18 months (6 June 2003 -13 December 2004). 


\section{GOLDEN PARACHUTES}

The essence of a preventive antitakeover defence called the golden parachute is concluding the contracts stipulating the rights of an engaged team of managers of the prospective target company and guaranteeing the payment of profitable compensation in case of occurrence of transactions related to takeover of control (buyoff of a certain percentage of shares or direct offer to shareholders for a certain percentage company shares). The fact that there are alternative events that may cause the implementation of this agreement made the difference between the golden parachutes that may be caused by a single "trigger", and those that may be caused by a double "trigger." The parachutes that may be caused by a double "trigger" are more efficient, whereas those caused by a single "trigger" are thought to be related to the rights that the employees and/or the members of the board of directors and the engaged team of managers grant themselves, without the shareholders' consent, representing one of the most flagrant examples of unlawful acts in a modern takeover age (Gaughan, 2015, p. 488).

As well as all other defences, that apart from being illegitimate are also considered to be designed to protect the interests of the engaged team of managers, the golden parachutes have their own supporters and critics. The pro et contra attitudes about the adoption of agreements called the golden parachutes can be summarized in the following manner (Radović, 2008, p. 42-5).

The author specifies the following reasons justifying the introduction of the golden parachutes:

- Promising high compensation in case of control change represents a wish to attract and retain qualified and competent individuals, able to lead a company in the most preferable direction;

- High compensation in case of control takeover represents a way of equalization of interests of shareholders and board members after the takeover procedure initiation;

- The golden parachutes increase the negotiating power of the management, leading, as a rule, to higher premiums of the target company shareholders, and

- The results of several empirical researches confirm the justification of the introduction of golden parachutes because of the following reasons: there is a positive correlation between the golden parachutes and takeover activity; the market price of shares of the corporations that adopted this kind of plan increases by an average of $3 \%$ after the disclosure, and the amount of compensation promised to the engaged team of managers is in direct proportion to the amount of the takeover premium. ${ }^{9}$

The opponents of the implementation of golden parachutes as an antitakeover defence present the following arguments:

- High compensation promised encourage board members to initiate takeover of the company they manage, even in cases when it is not economically justified, or in the best interest of shareholders. As the right to compensation arises from the control takeover, the management will be interested to enable the takeover, particularly in cases when the compensation earned on the basis of golden parachutes is higher that the difference of the anticipated compensation in the target corporation and the compensation on the basis of future earnings in another corporate entity;

$9 \quad$ For more details on the impact of golden parachutes on share price see: Lambert, R. A., Larker, D. F., "Golden Parachutes, Executive Decission Making an Shareholders Wealth," Journal of Accounting Economics 7, 1985., p. 179-203; Machlin, J., Choe, H., Miles, J., "The Effects of Golden Parachutes on Takeover Activity,“ Journal of Law and Economics 36, 1993., p. 861-76. 
- Introduction of golden parachutes is counterproductive, as it mostly includes rewarding the poor management (Lukić, 2020.). ${ }^{10}$ That is why there are suggestions that, in case of control takeover, the condition for payment of compensation to the engaged team of managers should be that over the past several years the corporation has not operated below that industry's average;

- Instead of giving the total amount of takeover premium to the target corporation shareholders, one of its parts would thus be redirected to the golden parachute holders, and

- High compensation to the golden parachute holders exclusively serves the interest of the management and board members (hypothesis on preservation of managerial chairs), making the position of the director untouchable and inviolable. That is why the opponents frequently call this defence measure 'golden handcuffs', as it ties the hands of a company, giving a great freedom to their holders.

The dissolution of Yugoslavia and the transition of the so-called Socialist Bloc of Eastern European countries from the planned and controlled to the market economy resulted in the development of the corporate forms of company organizing, and use of experience related to takeover tactics and/or antitakeover measures implemented by the corporations in the countries with the developed market economy. The lack of experience, or the intent to acquire certain unlawful benefits enabled conclusion and activation of the arrangements with an engaged team of managers even in the situations that, to say the least, had no relation with the intent to acquire or takeover the control over such companies, as those companies were mostly owned by the state. The following examples of the (un)intentional incorrect application support the critics of the golden parachutes, as there are several sources ${ }^{11}$ of texts claiming that some discharged directors and/or board members of both corporations and state-owned companies secured the mentioned rights for themselves, and in the developed market economy countries, those rights are usually granted to the directors of world-renowned corporations.

The first two mentioned texts refer to the application of the golden parachutes in NIS. The first text "Not employed, but earning EUR 5,000!" emphasizes that the "golden parachute managerial contract is usual in the largest and most successful global companies. These contracts protect the interests of managers on the highest positions even after the termination of their employment. At the same time they are protecting interests of the companies, as the managers may not transfer to another competitor in that period." Regardless of the fact that NIS is basically a state-owned company that almost holds a monopoly in the Republic of Serbia, its directors provided golden parachutes for themselves, so that "for two years after leaving their positions they will earn huge salaries on the basis of managerial contracts equal to the contracts of the directors of the largest global corporations like Sony, Toyota,..." ${ }^{\text {"12 }}$

The "Managerial contracts: "Golden parachutes" in a state-owned company, too" article deals with the "case" of the former director of the Novi Sad Fair, Dragan Lukač. His managerial contract specified that his salary would be "the fantastic EUR 2,600 in RSD equivalent

$10 \quad$ "These are the multimillion-dollar severance pays to managers leaving the companies after destroying them. The bosses do not want to accept the failure and therefore scare the shareholders, so they bribe the managers to leave because of "personal reasons"."

11 For more details, see the following articles: "Ne radi, a zarađuje po 5.000 evra," (www.pressonline.rs, accessed on 10 November 2020), "Šeik od NIS-a," (www.politika.rs, accessed on 10 November 2020), "Menadžerski ugovori: "Zlatni padobran“ i u državnoj firmi," (www.bizlife.rs, accessed on 10 November 2020).

12 www.pressonline.rs, accessed on 10 November 2020 
according to the middle exchange rate of NBS, and the "golden parachute" will be "activated" if the Supervisory Board discharges the director out of any reason." In case of discharge, the director would be entitled to the compensation in the amount of 12 gross salaries, to be paid in full to the discharged director within no more than 30 days from the date of termination of the directorial office. It would be interesting to mention that the director provided such benefits for 38 working hours a week, less than full-time working hours, as he simultaneously performed the function of the president of the Regional Chamber of Commerce. ${ }^{13}$

We found similar examples in the Republic of Croatia, too. Last year, the Croatian Association of Journalists (HND) protested against the fact that Goran Radman, former director of the Croatian Radio Television (HRT), prepared the golden parachutes for the selected managers and editors, ensuring a preferential status. The statement of HND claimed, among other, that the "special agreements for the selected editors and managers of HRT are unacceptable, as no criteria were published, and the agreements were made before the announced systematization of the jobs entered into force" and invited the colleagues who were granted golden parachutes in accordance with the director's criteria not to sign such agreements, and that such a move would be the only "moral and ethical act, not only to the colleagues, but more importantly, to the public." ${ }^{\text {"14 }}$ There is also an interesting text about the discharges of the president and two board members of the Hrvatske autoceste road company. The discharged managers will cost this company more than one million HRK, on the basis of rights arising from their contracts, although their discharge is not related to takeover, but to the unlawful acts (adverse contracts on tunnel painting; fictive employment; purchase of luxury cars for the company, etc.) (Pandžić, 2020.).

We would like to conclude the discussion about the golden parachutes with the statement that "they do not represent efficient means against takeovers, and that together with other measures, they may play a deterrent role." (Gaughan, 2015, p. 490)

\section{CONCLUSION}

The development of measures against the takeover implemented by the prospective target companies is the consequence of the development of new and more sophisticated takeover tactics used by the acquirers. The preventive takeover defence called the golden parachute represents one of the most significant, efficient and frequently used measures, even in the companies operating in the countries that do not have sufficiently regulated and developed corporate control markets. Establishing and complying with the system of values characterized by ability and competence, and not only political party affiliation, nepotism and other anomalies, will probably contribute to overcoming of issues occurring in the implementation of this measure in the companies and state-owned enterprises in former SFRY countries. Regardless of all deficiencies in the implementation of the golden parachute method in our conditions, we believe that the inclusion of this corporate governance mechanism is positive, and that the mentioned irregularities and (ab)uses in its implementation will be eliminated over time. 


\section{REFERENCES}

Auerbach, A. J. (ed.), (1988.), Mergers and Acquisitions, National Bureau of Economic Research, The University of Chicago Press, Ltd., London.

Bragg, S. M., (2014.), Mergers \& Acquisitions: A Comprehensive Guide, Accounting Tools, Inc., Colorado.

Brealey, R. A., Myers, S. C., Marcus, A. J., (2007), Fundamentals of Corporate Finance, Fifth edition, McGraw-Hill.

Ćirović, M., (2004.), Fuzije i akvizicije, Prometej, Novi Sad.

DePamphilis, D. M., (2015.), Mergers, Acquisitions, and Other Restructuring Activities, Eighth edition, Academic Press, San Diego.

Đorđević, S. M., (2007.), Poslovne kombinacije - Računovodstveni aspekt, monografija, Ekonomski fakultet Priština-Kosovska Mitrovica.

Gaughan, P. A., (2015.), Mergers, Acquisitions, and Corporate Restructurings, Sixth edition, John Wiley \& Sons, Inc., New Jersey.

Lambert, R. A., Larker, D. F., (1985.), "Golden Parachutes, Executive Decision Making an Shareholders Wealth,“"Journal of Accounting Economics 7.

Lukić, S., „Od Borisa do večnosti,“ (pescanik.net, accessed on 10 November 2020).

Machlin, J., Choe, H., Miles, J., (1993.), "The Effects of Golden Parachutes on Takeover Activity," Journal of Law and Economics 36.

Pandžić, I., "Smjena uprave HAC-a stajat će najmanje milijun kuna," (www.ncs.hr, accessed on 10 November 2020).

Predić, B., Ivanović-Đukić, M., (2010.), "Metod za rešavanje agencijskog problema,“" Ekonomske teme, 1/10, Ekonomski fakultet, Niš.

Radović, V., (2008.), “Zlatni padobrani, korporativno upravljanje i tržište korporativne kontrole," Pravo $i$ privreda 1-4, Udruženje pravnika u privredi Srbije, Beograd. https://www.harmonius.org/sr/publikacije/clanci/vuk_radovic/Vuk_1-4_2008.pdf

Ross, S. A., Westerfield, R. W., Jordan, B. D., (2006.), Corporate Finance: Fundamentals, $7^{\text {th }}$ Edition, Mc Graw-Hill International Edition.

Sudarsanam, S., (2003.), Creating Value from Mergers and Acquisitions, The Challenges, Prentice Hall, London.

Vasiljević, M., Radović, V., (urednici), (2008.), Korporativno upravljanje, Zbornik radova, Pravni fakultet, Beograd.

www.bizlife.rs, (accessed on 10 November 2020).

www.pressonline.rs, (accessed on 10 November 2020).

www.politika.rs, (accessed on 10 November 2020).

ezadar.rtl.hr. (accessed on 10 November 2020). 